\title{
Impact of International Law on the EU Customs Union
}

\author{
Achim Rogmann*
}

\begin{abstract}
This contribution examines the various international instruments, in both hard and soft law, that have been established by international organisations such as the WTO and WCO and scrutinises how they have been implemented into EU legislation governing the EU Customs Union, thus demonstrating the substantial influence of international instruments on the Customs Union. As the relevant international instruments affect not only the traditional elements of European customs law, but also the EU's entire export control regime and the framework of the internal market, this contribution demonstrates, moreover, how the Customs Union functions in a globalised world.
\end{abstract}

Keywords: European Union, customs union, international law, customs legislation, autonomous standards

\section{Introduction}

The year 2018 marked the fiftieth anniversary of the establishment of the EU Customs Union ('the Customs Union'). Whereas its fortieth anniversary was seen as an occasion worthy of celebrating, ${ }^{1}$ no such celebrations have been organised to mark the more remarkable event that the Customs Union has now been in operation for half a century. The main reason for the absence of celebrations is the decision by the United Kingdom to leave the Customs Union. This has raised questions about the role of the Customs Union in the future relationship between the EU and the United Kingdom. ${ }^{2}$ Although the primary effect of this situation may be of an economic nature, we should not forget that the Customs Union has historically also been valued as a 'tool for peace'. 3 'The fiftieth anniversary can therefore be seen as a good opportunity to analyse international law's impact on the continuing development of the Customs Union,

* Achim Rogmann, LL.M is professor of law at the Brunswick European Law School at Ostfalia Hochschule fur angewandte Wissenschaften.

1. See the special events organised to mark the Customs Union's fortieth anniversary, available at: http://ec.europa.eu/taxation_customs/ 40customs/index_en.htm (archived; last visited 11 October 2018) and European Parliament resolution, document P6_TA(2008)0305 (no equivalent for the more recent anniversary).

2. T. Lyons, 'Commentary: Customs Union: EU Foundation Stone, Brexit Stumbling Stone', 12(9) Global Trade and Customs Journal 344, at 346-47 (2017).

3. Ibid., at 344-45. as well as to demonstrate international law's strong impact on legislation governing the Customs Union. Article 28 of the Treaty on the Functioning of the European Union (TFEU) stipulates that the Union 'shall comprise a customs union which shall cover all trade in goods'. The Union Customs Code (UCC), ${ }^{4}$ by contrast, which was enacted to manage this Customs Union, sticks to the traditional wording that 'the Union is based upon a customs union', ${ }^{5}$ which demonstrates its fundamental role for the EU even more clearly. The development of the EU into the form we know today has always been deeply interrelated with the Customs Union, as manifested by Article 28 TFEU. The central piece of European customs legislation is now the UCC, which was enacted in 2013 and which, like the Customs Union itself, has evolved over time. The establishing of the latter on 1 July 1968, ahead of schedule, was considered simply as a starting point for a long series of additional steps, ${ }^{6}$ with the European Commission admitting in 1982 that a fully developed customs union was still a long way off. ${ }^{7}$ Even today, the Customs Union has still not been completed ${ }^{8}$ and continues to constitute a seemingly never-ending process of adapting to the everchanging challenges of world trade. And while the UCC $^{9}$ was enacted with the aim of modernising the Customs Union's legal framework, ${ }^{10}$ the European Commission, for example, still sees the need for the independent customs administrations in the member states to continue working towards acting as a single entity. ${ }^{11}$ Meanwhile the Commission's proposal for a directive on the Union's legal framework for customs infringements and sanctions ${ }^{12}$ is still pending, while a customs union without harmonised sanctions is deemed to be incomplete. ${ }^{13}$

As early as 1966, the European Court of Justice (ECJ) found the provisions governing the Customs Union to be of fundamental importance for establishing the free

\footnotetext{
4. EP and Council Regulation 952/2013, OJ 2013 L 269/1.

5. Lyons, above n. 2, at 345.

T. Lyons, EU Customs Law - 3rd edition (2018), at 33.

7. European Commission Programme for the Attainment of the Customs Union, 12 February 1982, COM(82) 50 final, at 3.

8. Lyons, above n. 2, at 346.

9. EP and Council Regulation 952/2013, OJ 2013 L 269/1.

10. On the various reasons for reforming customs law, see H.M. Wolffgang and K. Harden, 'The New European Customs Law', 10(1) World Customs Journal 3, at 3-4 (2016).

11. European Commission Communication $\operatorname{COM}(2016) 813$ final, at 4.

12. EP and Council Directive Proposal $\operatorname{COM}(2013) 884$ final.

13. T. Lyons, 'A Customs Union without Harmonized Sanctions: Time for Change?' 10 GTCJ 136-42 (2015).
} 
movement of goods. ${ }^{14}$ The prohibition on customs duties and charges having equivalent effect was designed to combat the obstacles to trade, created by such duties, between member states. ${ }^{15}$ While the ban on such duties and charges relates to the internal dimension of the single market, the Common Customs Tariff (CCT) governs trade with third countries or, in other words, the external dimension of the single market. The establishment of the CCT in 1968 was intended to achieve equalisation of customs duties and charges levied on products imported from third countries at the external borders of what was then the European Community so as to avoid deflecting trade with third countries and distorting free circulation and competitive conditions in the internal market. ${ }^{16}$ The Customs Union undoubtedly plays an indispensable role in virtually all the EU's other integration projects as the single market would be inconceivable without the Customs Union at its foundations.

But even though legislation governing the Customs Union is in the hands of the EU, the European legislator has to take numerous international instruments governing international trade into consideration, and these instruments will be evaluated in this context. On the one hand, EU customs and foreign trade law have been shaped primarily by the provisions of the World Trade Organization (WTO), in particular the General Agreement on Trade and Tariffs (GATT) 1994, while the Trade Facilitation Agreement (TFA) is also of particular relevance when it comes to trade facilitation and the growing recognition of this in the legislative procedure. On the other hand, the EU also has to take account of the World Customs Organization (WCO) with regard to the customs-specific provisions introduced through the Revised Kyoto Convention (RKC), adopted in 2006, and the SAFE Framework of Standards to Secure and Facilitate Global Trade (SAFE Framework), adopted in 2005.

The status of these international legal instruments differs according to whether they constitute hard law or soft law, and this status, in turn, affects the formation of the relevant EU legislation. With the exception of GATT 1994, all regulations are considered, to a certain extent, to be at least partially of a soft-law nature. Introducing soft-law rather than hard-law regulations with the former generally being seen as offering greater flexibility for non-state actors and lower contracting costs - has been indicated as being especially beneficial for facilitating trade. ${ }^{17}$

14. Cases 52 and 55/65, Germany v. Commission, [1966] ECR 00159, at 169; Case 115/02, Rioglass und Transremar, [2003] ECR I-12 705, at 18.

15. Cases 2 and 3/69, Sociaal Fonds voor de Diamantarbeiders/Brachfeld and Chougol, [1969] ECR 00211, at 15, 18.

16. Cases 37 and 38/73, Sociaal Fonds voor de Diamantarbeiders/Indiamex, [1973] ECR 01609, at 8-9; Case C-126/94, Cadi Surgelés and Others, [1996] ECR I-5647, at 14; Case C-173/05, Commission v. Italy, [2007], ECR I-4917, at 29.

17. H.M. Wolffgang and E. Kafeero, 'Old Wine in New Skins: Analysis of the Trade Facilitation Agreement vis-à-vis the Revised Kyoto Convention', 8(2) World Customs Journal 27, at 34 (2014); K. Abbott and

\section{EU Competences in the Field of the Customs Union}

Article 3(1)(a) TFEU defines the Customs Union as being an exclusive competence of the EU, while Article 3(1)(e) TFEU states that the EU also has exclusive competence in respect of a common commercial policy (CCP). Article 3(2) TFEU states that the Union additionally has 'exclusive competence for the conclusion of an international agreement when its conclusion is provided for in a legislative act of the Union or is necessary to enable the Union to exercise its internal competence.' According to Article 2(1) TFEU, exclusive competence means that 'only the Union may legislate and adopt legally binding acts,' while EU member states must refrain from doing so unless 'they are empowered by the Union or for the implementation of Union acts.' Given that domestic legislation is assigned merely a supplementary role in customs matters ${ }^{18}$ and given the requirement for this legislation to be in accordance with EU law, there is no need here to assess national customs provisions in any further detail.

Owing, however, to the principle of conferred powers, the EU may act only if it has been granted a legal basis for action in the treaties pursuant to Article 5(2) of the Treaty on European Union. The listing in Article 3 TFEU of the areas in which the EU has exclusive competence does not serve as a legal basis for enacting legal instruments. And despite customs legislation constituting a fundamental part of any customs union, the TFEU does not provide an express competence to adopt customs law. ${ }^{19}$ This gap has been filled by the adopting of the UCC, particularly with regard to Article 33 (customs cooperation), Article 114 (approximations of laws for the establishment and functioning of the internal market) and Article 207 (CCP) TFEU. Article 207 TFEU clarifies that the Union's exclusive competence in the field of the CCP extends both to autonomous measures and to the concluding of agreements (external competence), and including the implementation of these agreements (internal competence).

\section{The EU Customs Union in a Globalised World}

To understand the concepts in international law and the latter's role with regard to the EU Customs Union, it is helpful to shed some light on the requirements for establishing international standards in the fields of customs and public international trade law in a globalised world. Traders obviously face considerable barriers to

D. Snidal, 'Hard and Soft Law in International Governance', 54(3) International Organization 421, at 434 (2000)

18. S. Armella, EU Customs Code (2017), at 31

19. M. Lux, 'EU Customs Law and International Law', 1(1) World Customs Journal 19, at 21 (2007). 
trade if they have to deal with wide-ranging provisions and procedures that vary from one country or territory to the next. Not surprisingly, therefore, states were quick to appreciate the need to harmonise international trade rules in order to facilitate cross-border trade of goods. The origins of the international community's long-standing common interest in customs law can be seen as dating back to the Convention Concerning the Formation of an International Union for the Publication of Customs Tariffs, signed in $1890 .{ }^{20}$ Some two decades later, in 1923, the League of Nations hosted a conference that resulted in the signing of the International Convention relating to the Simplification of Customs Formalities. $^{21}$

Surprisingly, then, it was not until its Ministerial Conference in Singapore in 1996 that the WTO added 'trade facilitation' to its agenda. ${ }^{22}$ This was despite global rules for customs valuation, leading to a high degree of uniformity in assessing the customs value of imported goods, being adopted under the auspices of GATT 1947, which can be seen as a predecessor of the WTO. However, we have to keep in mind that the core idea for this model was not to facilitate trade, but rather to prevent the parties that had ratified GATT from undermining their distinct commitments to customs duties by using arbitrary customs valuation methods. ${ }^{23}$

Nowadays, trade facilitation is seen as comprising 'the simplification, harmonisation, standardisation and modernisation of trade procedures' in order to reduce trade transaction costs at the interface between business and government. ${ }^{24}$ Harmonisation is defined as 'the alignment of national formalities, procedures, operations and documents with international conventions, standards and practices', whereas standardisation has been described as 'the process of developing internationally agreed formats for practices and procedures, documents and information'. ${ }^{25}$ Trade facilitation is a genuinely interdisciplinary challenge since it is simultaneously a political, economic, business, administrative, technical and technological issue. ${ }^{26}$

The core drivers of trade facilitation are the WTO and the WCO. Numerous international conventions and instruments have been established, especially under the auspices of the WCO, with the aim of eliminating trade barriers in the field of customs legislation. These include the International Convention on the Harmonized Commodity Description and Coding System (HS Convention), the Revised International Convention on

20. 26 Stat. 1518 , Treaty Series 384; see Lyons, above n. 6 , at 19

21. League of Nations, Treaty Series, Volume 30, at 373

22. T. Butterly, 'Trade Facilitation in a Global Trade Environment', in C. Cosgrove-Sacks and A. Apostolov (eds.), Trade Facilitation: The Challenges for Growth and Development (2003) 29, at 35.

23. T. Einhorn, 'Customs Law, International', encyclopaedia entry, MPEPIL, at 28 (2014).

24. A. Grainger, 'Customs and Trade Facilitation: From Concepts to Implementation', 2(1) World Customs Journal 17, at 20 (2008); see also WTO, World Trade Report 2015, at 36

25. UN/CEFACT Recommendation No. 33 on Single Windows of 2005 Grainger, above n. 24, at 20

26. Butterly, above n. 22, at 32 . the Simplification and Harmonisation of Customs Procedures (the Revised Kyoto Convention, or RKC), ${ }^{27}$ the SAFE Framework and the Framework of Standards on Cross-border E-Commerce. ${ }^{28}$ In terms, however, of trade facilitation, the WTO's TFA, which entered into force in 2017, must also be highlighted, even though it contains almost exclusively elements derived from the RKC, but transposes them into hard law. ${ }^{29}$ Most of the commitments in the TFA were consequently already part of the EU customs regulatory framework under the Community Customs Code (CCC, 1992) and were further developed under the UCC in 2013. ${ }^{30}$

As the EU has also adopted all the relevant international instruments ${ }^{31}$ requiring it to transpose the customs law governing the EU Customs Union into national or regional customs law, this customs law has largely been designed to implement international customs rules. More or less the same applies to other areas of international trade law, given that the EU legislation governing the Customs Union is not restricted to customs provisions and the related issue of trade facilitation. The EU also operates the CCP, which, as an integrated part of EU external relations, aims to achieve balanced economic and social development worldwide through trade liberalisation, fair trade and integration into the world global economy. ${ }^{32}$ This has led to a remarkable number of legislative acts in the form of export control legislation, trade defence instruments, preferential trade arrangements and trade embargoes, all of which can be summarised under the heading of 'trade policy measures'.

International traders also have to cope with the challenge of crossing language barriers. The EU Customs Union itself has twenty-four official languages, ${ }^{33}$ while trade with third countries may also require accompanying documents to be supplied in the official language of the country of destination, which may not necessarily be an official EU language. In order to facilitate external trade, specific codes (such as tariff classification codes, customs procedure codes and INCOTERMS) rather than words have been adopted. In this respect, EU customs legislation governing the Customs Union also reflects the international efforts to achieve standardisation.

27. For conventions and agreements sponsored or administered by the WCO, see http://www.wcoomd.org/en/about-us/legal-instruments/ conventions.aspx.

28. For resolutions of the WCO, see http://www.wcoomd.org/en/aboutus/legal-instruments/resolutions.aspx.

29. Wolffgang and Kafeero, above n. 17, at 35

30. T. Cachet, 'The World Trade Organization Trade Facilitation Agreement: Legal Consequences and Impact on the Union Customs Code', 12(2) Global Trade and Customs Journal 74 (2017).

31. For the extent of their scope, see Lux, above n. 19, at $21 \mathrm{ff}$.

32. A. Dimopoulos, 'The Effect of the Lisbon Treaty on the Principles and Objectives of the Common Commercial Policy', 15(2) European Foreign Affairs Review 153, at 170 (2010).

33. Council Regulation 1, OJ 1958 17/385, consolidated text (1 July 2013). 


\section{Framework for}

\section{Implementing and Incorporating International Trade Law into EU Legislation}

To assess the impact of international law on the EU Customs Union we first need to consider the methods for transposing international law into Union law. International law may be reflected at the level of primary EU law (treaties) or in secondary and tertiary EU legislation.

The external dimension of the Customs Union is fundamentally influenced by international agreements on a wide range of aspects governing international trade in goods. Article 207 TFEU forms the basis of such agreements with regard to commercial policy measures, while Article 217 entitles the EU to negotiate and conclude association agreements, such as the existing agreements with Turkey or the Western Balkan states. The ECJ has also held that external competence may derive from other provisions of the TFEU and measures adopted within the framework of those provisions. The existence of internal rules or unexercised treaty powers ('implied power') to adopt such rules may also grant external competence to the EU. ${ }^{34}$

Once such agreements enter into force, their legal standing within the hierarchy of EU law is highly significant. Under Article 216(2) TFEU, agreements concluded by the Union are binding on the institutions of the Union and on its member states. Once an agreement enters into force, its provisions form an 'integral part' of EU law. ${ }^{35}$ $\mathrm{EU}$ agreements that enter into force are binding on the member states by virtue of their obligations under EU law, rather than under international law. ${ }^{36}$ The ECJ has held that international agreements are directly effective, providing certain conditions are fulfilled. The principle of the direct effect of EU law, as previously acknowledged by the ECJ ${ }^{37}$ requires the provision in question to be unconditional, its application not to be dependent on further action by the EU or member state institutions, and it to be sufficiently clearly defined. ${ }^{38}$ Whether an agreement can be directly effective depends on the specific agreement in question. In the case of GATT and now WTO law, the ECJ has concluded that because they are characterised by great flexibility, it is only under very specific circumstances that such multilateral agreements are capable of conferring individual rights

34. Case 22/70, Commission v. Council - European Agreement on Road Transport, [1970] ECR 01971, at 27 and 72-77.

35. Case 181/73, Haegeman, [1974] ECR 00449, at 5; Opinion 1/91; EEA Agreement I, [1991] ECR I-6079, at 37; Lyons, above n. 6, at 248

36. P. Craig and G. de Búrca, EU Law, 6th edition (2015), at 338.

37. Case 26/62, Van Gend en Loos, [1963] ECR 0001

38. Ibid., at II. that can be invoked by economic operators in national courts. ${ }^{39}$

In the Kupferberg case, ${ }^{40}$ however, the ECJ found the earlier free trade agreement between the European Economic Community (EEC) and Portugal to have direct effect as the provision in question was unconditional and sufficiently precise, and its direct application was within the purpose of the agreement. As a result, the Court declared this trade agreement to be directly enforceable. ${ }^{41}$ This position was further strengthened in the ECJ judgment on the legal effect of the former Lomé IV Convention on preferential market access for goods originating in $\mathrm{ACP}^{42}$ states, where the Court found the Convention able to confer rights on individuals that they may enforce in national courts in order to challenge the application of conflicting national provisions. ${ }^{43}$ Consequently, those parts of international agreements that are sufficiently precise are directly applicable, without any need to adopt implementing provisions. This applies especially to rules of origin or tariff concessions in preferential agreements. ${ }^{44}$ The Customs Convention on the International Transport of Goods under Cover of TIR Carnets has also been categorised as directly applicable, ${ }^{45}$ with the result that only some of its administrative provisions have had to be transposed into EU customs regulations. ${ }^{46}$ This option to integrate international agreements into EU law without express transposition means that the assessment of international law's impact cannot be restricted to the traditional written sources of EU law as laid down in the treaties or as adopted under Article 288 TFEU.

In some cases, international agreements that are directly applicable have nevertheless been transposed into EU law, such as where the EU is the contracting party to more than one convention on a specific subject and, for reasons of transparency, the EU legislation has been drafted to accommodate all these conventions' rules. In other cases, the EU may apply more generous rules than those adopted under the various conventions. ${ }^{47}$

In practice, however, most international agreements are not directly applicable and have to be expressly transposed into EU legislation. This transposition can be literal, or almost literal, if the wording of the international instrument can form the basis for the EU legislation, with more detailed rules then being added, if necessary. Examples of such agreements include the Harmonized Commodity Description and Coding System and the WTO Customs Valuation Agreement. ${ }^{48}$ In the field of export control law, non-proliferation arrangements form

39. Case C-280/93, Germany v. Commission, [1994] ECR I-4973.

40. Case 104/81, Hauptzollamt Mainz v. C.A. Kupferberg \& Cie. KG a.A., [1982] ECR 03641

41. Craig and De Búrca, above n. 36, at 345

42. African, Caribbean and Pacific.

43. Case C-469/93, Amministrazione delle Finanze dello Stato v. Chiquita Italia SpA, [1995] I-4533, at 31-35

44. Lux, above n. 19, at 21

45. Case C-78/01, BGL v. Germany, [2003] ECR I-9543, at 43

46. Lux, above n. 19, at 22

47. Ibid., at 22

48. Ibid., at 23 
the basis for the listing of goods in Annex I of the EU Dual-Use Regulation. ${ }^{49}$ This Regulation was adopted on the basis of the CCP (formerly Article 133 Treaty Establishing the European Community [TEC], now Article 207 TFEU) as the ECJ found in Leifer ${ }^{50}$ and Werner $^{51}$ that rules governing the export control of dualuse items also fall within this policy, which forms part of the EU's exclusive competence.

International law's impact on the EU Customs Union is intensified by the fact that EU law must be interpreted, as far as possible, in conformity with international agreements. ${ }^{52}$ Secondary EU legislation has to be interpreted in the light of the international obligations of the EU that stem from the wide scope of international instruments in the field of international trade. In general, it is already an obligation under international law to make full use of EU secondary legislation when interpreting EU law adopted in implementation of international law. This also avoids conflicts and leads to a harmonious and more coherent relationship between EU law and international law. ${ }^{53}$

Remarkably, the four non-proliferation arrangements implemented by the EU Dual-Use Regulation (i.e. the Wassenaar Arrangement, the Missile Technology Control Regime, the Nuclear Suppliers' Group and the Australia Group) are all of a nonbinding character since they are merely political understandings between participating countries rather than legally binding international agreements. By being implemented in the form of a regulation, these commitments become directly binding in all EU member states under Article 288 TFEU. The same mechanism applies to the SAFE Framework, which was compiled under the auspices of the WCO and constitutes the basis for the global introduction of the Authorised Economic Operator (AEO) instrument. This framework is likewise not a legally binding instrument, but rather a strong recommendation to national legislators to implement the agreed standards.

\section{Essential Elements of the Customs Union under WTO Law}

In general, a customs union means substituting a single customs territory for two or more customs territories,

49. Council Regulation 428/2009, OJ 2009 L 134/1

50. Case C-83/94, Criminal proceedings against Peter Leifer et al., [1995] ECR I-3231.

51. Case C-70/94, Fritz Werner Industrie-Ausrüstungen GmbH, [1995] ECR I-3189.

52. Case C-61/94, Commission v. Germany [1996] ECR I-3989, at 52; Case C-286/02, Bellio F.lli Srl, [2004] ECR I-3465, at 33; Case C-335/05, Rízení Letového Provozu ČR, s.p. v. Bundesamt für Finanzen, [2007] ECR I-4307 at 50.

53. K. Ziegler, 'The Relationship between EU Law and International Law', in D. Patterson and A. Södersten (eds.), A Companion to European Union Law and International Law (2016) 42, at 51. eliminating almost all restrictions on internal trade and applying substantially the same restrictions to external trade. ${ }^{54}$ The EU has followed the 'single customs territory' approach by defining the single customs territory of the Union. ${ }^{55}$

Owing to the EU's membership of the WTO, the traderelevant arrangements of the EU have to be in compliance with WTO rules. The Customs Union forms the basis for the single market, while WTO law, in turn, provides the basis for a customs union. In principle, WTO members recognise the desirability of regional trade agreements (RTAs), including customs unions, providing the purpose of these agreements is to facilitate trade between members of the customs union and not to raise barriers to the trade of other WTO members with the customs union (Article XXIV:4 GATT 1994).

Whereas a core objective of the multilateral trading system is to eliminate discriminatory treatment in international trade relations, ${ }^{56}$ RTAs pursue trade liberalisation through precisely this form of discrimination since the special preferences granted by the RTA are not available to other WTO members. This discrimination is made possible because WTO law provides for exceptions for regional integration purposes. These exceptions allow members to adopt and implement measures that would otherwise be WTO-inconsistent on the grounds, for example, that they breach the most favoured nation (MFN) obligation. ${ }^{57}$ Under Article XXIV: 5 GATT 1994, RTAs establishing customs unions or free trade areas may be justified even though they are otherwise WTO-inconsistent, but only if they comply with certain conditions.

Article XXIV:4 GATT 1994 sets out the goal of the exception provided for in Article XXIV:5, whereby the objective of signing an RTA should be to increase freedom of trade by developing closer integration and facilitating trade between the constituent territories rather than raising barriers to the trade of other members with such territories. Thus, the exception provided for in Article XXIV:5 GATT 1994 is designed to maximise the internal trade-liberalising effects of an RTA and to minimise its external trade-restrictive effects, as outlined in the Understanding on the Interpretation of Article XXIV GATT 1994.

However, Article XXIV:4 GATT 1994 does not in itself create a separate obligation, but rather explains the purpose of Article XXIV. The conditions for establishing the availability of a defence under Article XXIV must

54. Art. XXIV:8(a), 8(a)(i) and (ii) GATT 1994; see A.D. Mitchell and N. Lockhart, 'Legal Requirements for PTAs under the WTO', in S. Lester and B. Mercurio (eds.), Bilateral and Regional Trade Agreements, Commentary and Analysis (2009) 81, at 85.

55. EP and Council Regulation 952/2013, OJ 2013 L 269/1, Art. 4; see also the definition of 'customs union' in the WCO Glossary of International Customs Terms, available at http://www.wcoomd.org/en/topics/ facilitation/instrument-and-tools/tools/glossary-of-internationalcustoms-terms.aspx.

56. Marrakesh Agreement Establishing the World Trade Organization of 15 April 1994, 1867 U.N.T.S. 154, 33 I.L.M. 1144, Preamble, at 3.

57. Einhorn, above n. 23, at 40 . 
therefore be interpreted in the light of the purpose of RTAs as set forth in Article XXIV:4. ${ }^{58}$

There are two conditions under which Article XXIV:5 GATT 1994 may serve as a possible defence of a breach of GATT provisions: a measure otherwise inconsistent with GATT is justified under Article XXIV if:

- the measure is introduced upon the formation of a customs union, a free trade area or an interim agreement that meets all the requirements (emphasis added) set out in WTO law; and

- the formation of the customs union or free trade area would be prevented if the introduction of the measure concerned were not allowed ('necessity test'). ${ }^{59}$

This part of Article XXIV:5 GATT 1994, laying down the general conditions for the exception, is referred to as the 'chapeau' of para. 5.

\subsection{Impact on the Internal Dimension of the Customs Union}

The main impact of international instruments is seen to be on the EU's relationships with third countries. ${ }^{60}$ Compared to this external dimension, international instruments' influence on the internal relationships between members of a customs union can be seen as relatively low. The core provision in this respect is Article XXIV:8(a)(i) GATT 1994, which requires members of a customs union to eliminate duties and other restrictive regulations of commerce with respect to 'substantially all the trade between the constituent territories of the customs union or at least with respect to substantially all the trade in products originating in such territories'. Obviously, the first of these two options serves to liberalise trade, and the founding members of the EEC opted for a model that would not restrict the free movement of goods to goods originating in the EEC because the community was designed to be based on the least bureaucratic model for internal trade. ${ }^{61}$

Under Article 28(2) TFEU, the concept of the free movement of goods applies to all products originating in EU member states and to third-country products that are in free circulation in the internal market. In this regard, free circulation is granted to products from third countries that have complied with the specific formalities pertaining to import and customs duties pursuant to Article 29 TFEU. Products entitled to be in free circulation are definitively and wholly assimilated to products originating in any of the member states; in other words, both types of products are included, without distinction, in the same system of free circulation. ${ }^{62}$ Articles $28(2)$

58. AB report in Turkey - Textiles of 22 October 1999, WT/DS34/AB/R, at 57.

59. Ibid., at 58

60. Lyons, above n. 6, at 209

61. Lyons, above n. 2, at 345. Nearly all customs unions follow this model. An example of a customs union restricted to goods originating in member states is the CARICOM customs union, in which the free movement of goods is restricted to goods of community origin; see Art. 79 of the Revised Treaty of Chaguaramas Establishing the Caribbean Community including the CARICOM Single Market and Economy (2008).

62. Case 41/76, Donckerwolcke, [1976], ECR 01921, at 17, 21. and 29 TFEU constitute a fundamental part of the customs provisions for the functioning of the EU single market. Although the TFEU does not specify how goods may receive the status of Union goods, this essential detail is clarified in the UCC. Through this provision, the UCC functions as a 'gateway to the single market'.

In order to establish a customs union, internal restrictions have to be eliminated for 'substantially all the trade'. Unfortunately, the WTO member states have never reached agreement on how to interpret the term 'substantially'. ${ }^{63}$ In the Turkey - Textiles case, the Appellate Body (AB) noted that 'substantially all the trade' is not the same as 'all the trade', and also that 'substantially all the trade' is considerably more than merely 'some of the trade'. Even if the terms of Article XXIV(8)(a)(i) offer 'some flexibility' to the constituent members of a customs union when liberalising their internal trade, the degree of flexibility allowed is limited by the requirement for 'duties and other restrictive regulations of commerce' to be 'eliminated with respect to substantially all' internal trade. The EU shares the widespread opinion that the 'substantially all the trade' criterion is fulfilled as soon as $90 \%$ of the trade between the parties in an RTA is liberalised. ${ }^{64}$ Even though the United States may take the view that all product groups have to be covered by an RTA, ${ }^{65}$ the EU's deep integration through its single market, covering the free movement of goods, indisputably meets the need for internal trade liberalisation required under Article XXIV GATT 1994. ${ }^{66}$

How 'other restrictive regulations of commerce' subject to internal liberalisation should be understood is not entirely clear. Although WTO members pledged to clarify this term during the Doha Round, no substantial outcome has yet been achieved. However, the required depth of integration should not be overemphasised as federal states, such as the United States and Germany, are able to grant at least some flexibility to their constituent states and do not demand the harmonisation of all the regulations that might affect trade. Given the high degree of integration, including the ban on internal regulations hindering trade (i.e. measures having equivalent effect to quantitative restrictions under Article 34 TFEU), there can again be no doubt that the EU Customs Union is dealing with the other restrictive regulations of commerce in a W'TO-compliant way. ${ }^{67}$ Mathis even suggests taking the EU model as an essential stand-

63. A. Parenti, 'Accession to the World Trade Organisation: A Legal Analysis', 27(2) Legal Issues of Economic Integration 141, at 147 (2000).

64. See, e.g., European Commission (DG Trade) fact sheet on the interim Economic Partnership Agreements of January 2009, tradoc_142188, at 3; WTO document TN/RL/W/190, submitted by the Delegation of Japan, at 1

65. A. Alavi, 'Preferential Trade Agreements and the Law and Politics of GATT Art. XXIV', 1(1) Beijing Law Review 7, at 11 (2010).

66. Lyons, above n. 2, at 345.

67. J.H. Mathis, 'Regional Trade Agreements and Domestic Regulation: What Reach for 'Other Restrictive Regulations of Commerce"', in L. Bartels and F. Ortino (eds.), Regional Trade Agreements and the WTO Legal System (2006) 79, at 91. 
ard for establishing a customs union in general, given that this would prevent RTAs that provide for less deep forms of integration. ${ }^{6}$

The degree of flexibility provided under Article XXIV GATT 1994 entitles constituent members of a customs union to impose certain safeguard measures on imports from other members of the customs union. The internal trade requirement does not impose an obligation on the constituent members to eliminate internal borders and internal border inspections concerning value added tax, excise taxes or prohibitions and restrictions. This explains why the establishment of the Customs Union was not meant to abolish the national customs and tax frontiers within the customs territory. It was not until 1993 that the internal frontiers laid down in Article 7a EC Treaty (now Article 26.2 TFEU) were removed.

\subsection{Impact on the External Dimension of the Customs Union}

A customs union is frequently described as a more developed free trade area, in which member countries apply a common external tariff. ${ }^{69}$ However, Article XXIV:8(a)(ii) GATT 1994 requires the constituent members of a customs union to apply substantially the same duties and other regulations of commerce to trade with third countries. Hence, the common external trade regime required has to cover duties and also other regulations of commerce.

With regard to the term 'same', the AB in Turkey - Textiles $^{70}$ found something closely approximating 'sameness' to be required by Article XXIV:8(a)(ii) GATT 1994. This does not mean that the members of a customs union are obliged to harmonise all external trade restrictions or to adopt an identical external trade regime, although most areas of foreign trade provisions will move towards uniform standards. However, the Article requires a higher degree of sameness than just 'comparable trade regulations having similar effects'. And although 'sameness' of other regulations of commerce does not automatically mean these regulations have to stem from international rules, any autonomous rules the EU applies will have to abide by international standards that may be applicable, such as the need to apply substantially the same external trade rules for all members of the Customs Union.

The need to apply substantially the same duties requires members of a customs union to adopt a common external tariff for at least most goods. The CCT replaced the national customs tariffs of the member states with effect from 1 July 1968. The ECJ found this replacement to be in accordance with Article XXIV GATT 1994. ${ }^{71}$ This customs tariff has to comprise a nomenclature and the rates for the individual tariff lines. Both these elements

68. Ibid., at 91

69. P. Hilpold, 'Regional Integration According to Art. XXIV GATT: Between Law and Politics', in A. von Bogdandy and R. Wolfrum (eds.), Max Planck Yearbook of United Nations Law, Volume 7 (2003) 219, at 226.

70. AB report in Turkey - Textiles of 22 October 1999, WT/DS34/AB/R, at para. 50.

71. Case 38/75, Douaneagent der NV Nederlandse Spoorwegen v. Inspecteur der Invoerrechten en Accijnzen, [1975] ECR 1439, at 14. are significantly influenced by international rules, which will be addressed in this context.

With no definition of the term 'other regulations of commerce', it is no surprise that it is still disputed which measures of the constituent members of a customs union are covered by this term. ${ }^{72}$ Negotiations during the Uruguay Round to clarify whether 'other regulations of commerce' comprise internal measures, such as sales taxes and price controls, did not result in any explicit guidance or interpretation. Moreover, the use of the word 'customs' in Article XXIV:8 GATT 1994 was seen as an indication that the provision is restricted to measures applied at borders. It would be intrusive to oblige members of a customs union to apply substantially the same internal measures to goods, either limited to goods imported from third countries or even extending to trade within the customs union. ${ }^{73}$ This would result in sales taxes, as internal measures, being subject to harmonisation. The panel's approach in the Turkey - Textiles case $^{74}$ of demanding harmonisation of all the regulatory measures that could possibly affect trade included domestic regulations such as environmental standards. However, setting nearly unattainable standards for the establishment of customs unions would not be helpful as this would prevent states from pursuing regional integration. ${ }^{75}$ Hence, we should follow the AB's approach by taking Article XXIV:8(a)(ii) GATT 1994 to mean that the members of a customs union should be required to adopt 'a common external trade regime'. ${ }^{76}$ If we see the WCO's definition of the term 'customs union' as being restricted in terms of standards for external trade to 'a common Customs tariff and a common or harmonised Customs legislation for the application of that tariff, 77 we have to admit that these common rules form the basis for customs law only, but not for the full scope of foreign trade provisions.

Getting sovereign states to agree on such a common external trade regime by harmonising external trade rules regulating trade with third countries is already extraordinarily challenging. Imposing the additional obligation to harmonise internal market measures would mean there would be no automatic gain for the customs union's objective of maximising the trade-liberalising effects on internal trade while minimising the restrictive

72. WTO Committee on Regional Trade Agreements, 'Note on the Meetings of 6-7 and 10 July 1998', WT/REG/M/18 (22 July 1998); J.A. Crawford and S. Laird, 'Regional Trade Agreements and the WTO', CREDIT Research Paper 2000 No. 00/3, at 12; Mitchell and Lockhart, above n. 54, at 105

73. Mitchell and Lockhart, above n. 54, at 105.

74. Panel report in Turkey - Textiles of 31 May 1999, WT/DS34/R, at 9.120.

75. J.H. Mathis, Regional Trade Agreements in the GATT/WTO - Art. XXIV and the Internal Trade Requirement (2002), at 251; Mathis, above $\mathrm{n}$. 67 , at 91.

76. AB report in Turkey - Textiles of 22 October 1999, WT/DS34/AB/R, at 49.

77. Definition of 'customs union' in the WCO Glossary of International Customs Terms, available at: http://www.wcoomd.org/en/topics/ facilitation/instrument-and-tools/tools/glossary-of-internationalcustoms-terms.aspx. 
effects on other WTO members. ${ }^{78}$ The scope of the term 'other regulations of commerce' should therefore be restricted to border measures for goods imported from (or exported to) third countries. Even if the exact scope of 'other regulations of commerce' remains unclear, the term would clearly seem not to be congruent with the term 'other restrictive regulations of commerce', as discussed with regard to the internal dimension of a customs union. ${ }^{79}$

But even if the term 'other regulations of commerce' is interpreted narrowly, it will nevertheless include all administrative rules regulating importation, quantitative restrictions and import prohibitions, rules of origin and safeguard measures ${ }^{80} \mathrm{We}$ can conclude, therefore, that customs law comprises a need for harmonisation, but that the EU's Customs Union is not just about customs. ${ }^{81}$

The fact that the EU established a single market rather than just a customs union has even increased the economic pressure to harmonise the external trade regime. It was the single market that led to the removal of the internal frontiers between member states of the Customs Union. Internal border controls could be used to allow different VAT rates and market access provisions (such as prohibitions and restrictions) in the individual member states. However, non-harmonised regulations would then automatically lead to trade deflection since products imported from a third country and released for free circulation could then circulate freely within the Customs Union territory. While the provisions of international law evaluated below primarily address and refer to legislation in relation to customs and external trade matters, the extent to which they also affect the internal market should not be underestimated. This reflects the deep-rooted relationship between the single market and the Customs Union, which is here described only superficially.

Article XXIV:5(a) GATT 1994 also implies that duties and other regulations of commerce, applicable after the formation of a customs union, must not be higher in total or more restrictive than the general incidence of the duties and other regulations of commerce applicable before the customs union was created. This comparison of the general incidence should be based on an overall assessment of weighted average tariff rates and customs duties collected. ${ }^{82}$ Fifty years after the EU Customs Union was formed, this requirement is no longer an issue. However, this specific provision still has to be taken into consideration with regard to any potential enlargement of the EU since an acceding nation may have to increase its import duties when switching from its former national tariff to the EU's common external tariff.

\footnotetext{
Mitchell and Lockhart, above n. 54, at 105.

Mathis (2002), above n. 75, at 252-53

Mitchell and Lockhart, above n. 54, at 104.

Lyons, above n. 2, at 348-49.

WTO, Para. 2 of the Understanding on the Interpretation of Art. XXIV GATT.
}

If a constituent member of a newly formed customs union has to increase a bound duty, Article XXIV:6 GATT 1994 requires the procedure for modification of schedules (Article XXVIII GATT 1994) to be applied, with the objective of achieving a mutually satisfactory compensatory adjustment. ${ }^{83}$ Here, the reduction already afforded in the corresponding duty of other constituent members of the customs union will be taken into account.

\subsection{Scope of Measures Covered by the Exception under Article XXIV GATT 1994}

Article XXIV GATT 1994 contains conditions that have to be complied with by members of a customs union. In turn, it grants authorisation to deviate from obligations under world trade law. In Turkey - Textiles, the $\mathrm{AB}$ stated that the words 'shall not prevent' in Article XXIV:5 mean that 'the provisions of the GATT 1994 shall not make impossible the formation of a customs union.' Thus, Article XXIV:5 provides a defence against a claim that a customs union is inconsistent with any provision of GATT 1994. The most common standard in which an RTA seeks an exception is the MFN obligation under Article I:1 GATT 1994. Any customs union automatically discriminates against WTO members who are not a constituent member of the specific customs union. Because Article XXIV:5 GATT 1994 applies to inconsistencies with regard to GATT 1994 itself, it is not clear whether it may justify measures applied by a customs union that are inconsistent with other WTO agreements on goods, such as those annexed to GATT (e.g. the Agreement on the Application of Sanitary and Phytosanitary Measures, the Technical Barriers to Trade Agreement, or the Agreement on Customs Valuation Aims). Based on the existing case law on Article XXIV:5 GATT 1994, whether these exceptions can be extended to provisions in these agreements will depend on whether there is a close relationship between the provisions and GATT 1994 and whether the exception in Article XXIV has been incorporated into the specific agreement. ${ }^{84}$

However, only measures adopted upon formation of a customs union fall within the Article XXIV:5 exception. ${ }^{85}$ WTO-inconsistent measures added to the terms of a customs union after the RTA has been established would not be covered by the exception and may, therefore, be challenged by other WTO members for breaching WTO commitments. Moreover, the exception is restricted to the measures necessary for the formation of an RTA and can be used 'only to the extent that the formation of the customs union would be prevented if the introduction of the measures were not allowed' ('necessity test'). ${ }^{86}$ There are good reasons for applying a

83. For the accession of Croatia to the EU, see, e.g., Council Decision 1030/2018, OJ 2018 L 185/1.

84. See $A B$ report in Turkey - Textiles of 22 October 1999, WT/ $D S 34 / A B / R$, at 13.

85. Ibid., at 20; P. van den Bossche and W. Zdouc, The Law and Policy of the World Trade Organization - 4th edition (2017), at 680.

86. See AB report in Turkey - Textiles of 22 October 1999, WT/ $D S 34 / A B / R$, at 46 . 
necessity test to external trade restrictions only and not to internal trade restrictions between the parties in an RTA.

\section{International Instruments Implemented into the EU's External Trade Regime}

As we have seen, the core task of establishing and maintaining a customs union is to achieve a common external trade regime. When adopting the common provisions needed for such a regime, it is essential, therefore, to consider the international instruments that will have to be implemented for that purpose.

\subsection{Multilateral Agreements under the WTO} Under Article II:2 of the Marrakesh Agreement Establishing the World Trade Organization (WTO Agreement), the agreement itself and the associated legal instruments included in Annexes 1 to 3 form the 'Multilateral Trade Agreements'. These are integral parts of the WTO Agreement and binding on all WTO members. As the EU is also a member of the WTO in its own right, the Union has to implement all trade-relevant provisions of the WTO package when establishing a common external trade regime. In this context, the EU can restrict its efforts to provisions only relevant for trade in goods, with most of these provisions being found in Annex 1A. ${ }^{87}$ Annex 1A includes GATT 1994, twelve agreements, six understandings and the Marrakesh Protocol to the GATT 1994 concerning implementation of agreed tariff reductions. ${ }^{88}$ This does not automatically mean that other elements of WTO law can be fully ignored when establishing a customs union, as demonstrated by the border enforcement procedures provided for in the Agreement on Trade-Related Aspects of Intellectual Property Rights (TRIPS), ${ }^{89}$ which enables right holders to prevent customs authorities from releasing infringing imports into free circulation. The special requirements relating to border measures are contained in Section 4 of the enforcement part of the TRIPS Agreement and have been transposed into EU legislation by adoption of Regulation (EU) No. $608 / 2013 .{ }^{90}$

Numerous provisions impacting on the EU foreign trade regime can be found in GATT 1994. I will address those of most relevance. Article I:1 obliges WTO members to accord automatically and unconditionally to all WTO members any trade advantage they have granted to another nation (MFN principle). It thus prohibits treating some WTO members more preferen-

87. See P.C. Mavroidis, Trade in Goods, 2nd edition (2012), at 46.

88. Ibid., at 49

89. Agreement on Trade-Related Aspects of Intellectual Property Rights of 15 April 1994, in Marrakesh Agreement Establishing the World Trade Organization, Annex 1C, 1869 U.N.T.S. 299, 33 I.L.M. 1197

90. EP and Council Regulation 608/2013, OJ 2013 L 181/15. tially than others. This ban on discrimination covers customs duties imposed on or in connection with importation and exportation, rules and formalities applying to importation and exportation (especially customs provisions and procedures), and specific internal measures. ${ }^{91}$ This means equivalent import duties have to be applied to goods originating in WTO member states. The duties arising from the EU customs tariff apply, for all parties, to all imports to which no specific duty rules (trade preferences) apply.

Article V GATT 1994 provides for freedom of transit. Goods moved in transit will be exempt from customs duties and from all transit duties or other charges imposed in respect to transit, except specific transportation or service charges. Furthermore, they will not be subject to any unnecessary delays or restrictions. ${ }^{92}$ The EU has implemented this provision through Articles 226 to 232 UCC, thus allowing non-Union goods to move from one point to another within the customs territory of the Union without being subject to import duties or other charges.

Article VIII GATT 1994 allows WTO members to levy fees and charges for services rendered on or in connection with importation and exportation, but any such fees and charges must be limited in amount to the approximate cost of the services rendered (Article VIII:1). Under Article 52 UCC, customs authorities managing the EU Customs Union must not impose charges for the performance of customs controls or any other application of the customs legislation during the official opening hours of their competent customs offices. Only in specified cases may customs authorities levy fees. As the limitation provision of Article VIII:1 GATT 1994 has not been transposed into the UCC, it must be found in national law.

Article X:3(a) GATT 1994 imposes the obligation to administer all trade-relevant provisions in a 'uniform, reasonable, and impartial' manner. The United States challenged the management of the EU Customs Union in the EC-Selected Customs Matters case. ${ }^{93}$ Here, the panel held that the EU was violating Article $\mathrm{X}: 3(\mathrm{a})$ GATT 1994 because identical products within its sovereignty were subject to different treatment by the various customs administrations of the EU member states (the fact, for example, that LCD monitors were classified under different tariff headings resulted in import duty of $14 \%$ in one member state and $0 \%$ in the other). In this and other scenarios, ${ }^{94}$ the panel held that the EU was in violation of Article X:3(a) GATT 1994, ${ }^{95}$ while finding that the term 'uniform' also covers geographic uniformity and, additionally, that granting different

91. Mavroidis, above n. 87 , at 135 .

92. Van den Bossche and Zdouc, above n. 85, at 512.

93. WT/DS315.

94. See D. Rovetta and M. Lux, 'The US Challenge to the EC Customs Union', 2(5) Global Trade and Customs Journal 195 (2007).

95. Panel report in EC - Selected Customs Matters of 16 June 2006, WT/ DS315/R, at 7.305. 
treatment to identical products within its sovereignty violated Article X GATT 1994. ${ }^{96}$

This obligation under international law creates a specific challenge for the EU Customs Union, given that it is decentrally administered by twenty-eight national customs administrations and that the EU does not have a right to issue instructions to member states' customs administrations, ${ }^{97}$ even though member states are obliged to ensure the thorough, uniform and effective application and enforcement of EU law. ${ }^{98}$ However, the fact that EU customs law is administered by national customs authorities does not in itself lead to a breach of Article X:3(a) GATT. ${ }^{99}$

Nevertheless, WTO members have to provide for procedures, mechanisms and institutions to prevent divergences in customs administrations and to remove divergences if they occur. ${ }^{100}$ Article 197(1) TFEU legitimates the establishment of regulations to ensure the uniform implementation of EU law, while Article 291(2) TFEU recognises that a uniform implementation of legally binding Union acts can justify conferring implementing powers on the Commission. ${ }^{101}$ In recent years, the EU has intensified its efforts to enhance uniform administration of customs law, ${ }^{102}$ especially the enacting of the UCC aims, in line with today's need to offer greater legal certainty and uniformity for the benefit of businesses and customs administrations alike. ${ }^{103}$ However, the Commission's still pending proposal for a directive on the Union legal framework for customs infringements and sanctions in this context is a suitable example of the need to further implement the requirements laid down in international law, including Article X:3(a) GATT, as the risk of exploitation by noncompliant business parties in this situation constitutes a clear distortion of the internal market. ${ }^{104}$

Annex $1 \mathrm{~A}$ to the WTO Agreement includes twelve agreements that impact on the EU Customs Union at varying levels (anti-dumping, agriculture, textiles and clothing, customs valuation, import licensing, pre-shipment inspections, rules of origin, subsidies and countervailing measures, safeguards, sanitary and phytosanitary measures, technical barriers to trade, and trade-related

96. Panel report in EC - Selected Customs Matters of 16 June 2006, WT/ DS315/R, at 7.135; Mavroidis, above n. 87, at 829.

97. For the role, competences and strategies of the European Commission, see K. Limbach, Uniformity of Customs Administration in the European Union (2015), at $199 \mathrm{ff}$.

98. Case C-486/12, Gerechtshof te 's-Hertogenbosch v. Netherlands, [2013] ECR I-0, at 19; Case C-508/12, Vapenik, [2014] ECR I-0, at 23.

99. Panel report in EC - Selected Customs Matters of 16 June 2006, WT/ DS315/R, at 7.141; Limbach, above n. 97, at 52.

100. Panel Report in EC - Selected Customs Matters of 16 June 2006, WT/ DS315/R, at 7.144; Rovetta and Lux, above n. 94, at 207; Limbach, above n. 97, at 51-52

101. J.M. Grave, 'The Impact of the Lisbon Treaty on Customs Matters: A Legal Assessment', 5(3) Global Trade and Customs Journal 95, at 110 (2010); Limbach, above n. 97, at 163-64.

102. With regard to tariffs, see E. Valerdi Rodriguez and E. Dulguerova, 'Blues at the Border: The Quest for Uniform Tariff Classification in the European Union', 8(11/12) Global Trade and Customs Journal 368, at 375 ff. (2013).

103. Commission Report $\operatorname{COM}(2018) 39$ final, at 3 .

104. Lyons, above n. 13, at 142. investment measures). ${ }^{105}$ With the exception of the Agreement on Textiles and Clothing, which was terminated in 2005, the other agreements are still binding on all WTO members. A new agreement was added to the list of Annex 1A agreements in 2017. This followed the negotiations at the 2013 Bali Ministerial Conference, when WTO members concluded negotiations on the TFA. ${ }^{106}$ This ultimately entered into force on 22 February 2017, after sufficient numbers of WTO members had ratified a Protocol of Amendment to insert it into Annex $1 \mathrm{~A}$ of the WTO Agreement. ${ }^{107}$

The core trade-facilitation instruments provided for under the TFA involve the simplification, modernisation and harmonisation of export and import processes in order to address bureaucratic burdens and ineffective border procedures identified as significant barriers to international trade. Accordingly, the TFA contains provisions for expediting the movement, release and clearance of goods by clarifying and improving the relevant Articles (V, VIII and X GATT 1994). As one of the parties ratifying the TFA, the EU is obliged to implement the agreement in its customs legislation. But, as already pointed out, the UCC was enacted before the TFA was signed, and most of the elements had already been incorporated into EU customs legislation. ${ }^{108}$

Some of the other Annex 1A agreements have been literally, or almost literally, transposed into EU customs legislation, thus demonstrating a high level of impact. This applies in the case of the Agreement on Pre-Shipment Inspection, ${ }^{109}$ the Customs Valuation Agreement ${ }^{110}$ and the Anti-Dumping Agreement, ${ }^{111}$ as well as the Agreement on Subsidies and Countervailing Measures $^{112}$ and the Agreement on Safeguards. ${ }^{113}$ As far as setting a framework for EU legislation is concerned, the other Annex 1A agreements are restricted to having to be taken into consideration in the drafting of relevant trade rules. In these cases, the EU has transposed the objective, rather than the exact wording, of these international instruments into EU legislation.

\subsection{WCO Instruments}

Most international instruments relevant for the EU Customs Union have been drawn up under the auspices of the $\mathrm{WCO}^{114}$ since the latter is the only international body focusing exclusively on customs matters. The

105. Published in OJ 1994 L 336/22-189.

106. A. Grainger, 'The WTO Trade Facilitation Agreement: Consulting the Private Sector', 48(6) Journal of World Trade 1167, at 1167 (2014).

107. WTO General Council Protocol of 28 November 2014, WT/L/940.

108. Cachet, above n. 30.

109. Implemented by Council Regulation (EC) 3287/94, OJ 1994 L 349/79.

110. Implemented by EP and Council Regulation 952/2013, OJ 2013 L269/1, Arts. 70, 74; Commission Delegated Regulation (EU) 2015/2446, OJ 2015 L 343/1, Art. 37 No. 12; Commission Implementing Regulation (EU) 2015/2447, OJ 2015 L 343/558, Recital at 26.

111. Implemented by EP and Council Regulation 2016/1036, OJ 2016 L $176 / 22$.

112. Implemented by EP and Council Regulation 2016/1037, OJ 2016 L $176 / 55$.

113. Implemented by EP and Council Regulation 2015/478, OJ 2015 L $83 / 16$.

114. The official name is still the 'Customs Cooperation Council'. 
EU's full membership of the WCO is pending as the necessary amendment of the relevant convention still has to be ratified by all WCO members. To address this issue, WCO members have adopted a decision to confer rights 'akin to' membership to the EC (now EU) on an interim basis, pending formal amendment of the convention. ${ }^{115}$ WCO instruments are introduced in both legally binding (i.e. conventions) and non-legally binding forms (i.e. guidelines, recommendations and practices). In the absence of a single undertaking approach, members of the WCO are not under any obligation to adopt WCO instruments.

The WCO developed and administers the Convention on the Harmonized Commodity and Coding System (HS). This is the global nomenclature system for goods and is applied by more than 200 countries, territories or economic unions. ${ }^{116}$ The EU and its member states are parties to the HS. The core function of the HS is to describe the goods to which a specific rate of duty is applied. ${ }^{117}$ The list of goods contained in the Annex of the HS Convention has been incorporated word for word - with some additional levels of tariff lines - into the EU's Regulation governing the CCT. ${ }^{118}$ Owing to its precision, the HS Convention has direct effect and, as a result, the EU does not publish changes to the HS in its Official Journal. ${ }^{119}$ The EU's Combined Nomenclature serves both for customs purposes and as a basis for the external trade statistics of the $\mathrm{EU}^{120}$ and other Union policies concerning the importation and exportation of goods. ${ }^{121}$

In 1973, WCO members concluded the Kyoto Convention, which was the first global instrument aimed at simplifying and harmonising customs procedures and practices. ${ }^{122}$ This was later revised and updated in the RKC to meet government and private sector demands. The RKC was adopted in 1999 and entered into force in 2006. The EU (and its member states) notified accession to the RKC in March 2003. ${ }^{123}$ While it is remarkable to see how the WCO has sought to achieve the highest degree of harmony and uniformity in its customs systems, especially by means of the RKC, ${ }^{124}$ this uniformity obviously cannot be as extensive as the harmonisation of the external trade regime required in a customs union.

Even if the RKC is seen as the global standard for modern customs legislation, its awkwardly shaped structure and the number of elements it contains that lack precise

115. T. Yamaoka, 'The De Facto Accession of the European Communities to the World Trade Organization: Process and Significance', 8(4) Global Trade and Customs Journal 92, at 97.

116. See the list of parties applying the HS, available at: http:// www.wcoomd.org/-/media/wco/public/global/pdf/topics/ nomenclature/overview/hs-contracting-parties/list-of-countries/ countries_applying_hs.pdf?db=web (last visited 10 October 2018).

117. Lyons, above n. 2, at 156.

118. Council Regulation 2658/87, OJ 1987 L 256.

119. Lux, above n. 19 , at 23

120. Art. 1(1) of Council Regulation 2658/87, OJ 1987 L 256.

121. Lyons, above n. 2, at 156.

122. Armella, above n. 18 , at 20

123. Council Decision 2003/231, OJ 2003 L 86/21.

124. See considerations to the original Kyoto Convention. provisions mean it cannot be used as a model customs agreement. ${ }^{125}$ Furthermore, the EU has not adopted the specific annexes included in the RKC. ${ }^{126}$ But despite relevant parts of the RKC not being legally binding on the EU, the UCC shows a high degree of conformity with provisions of the $\mathrm{RKC}$ in some respects, even though the terminology is not necessarily equivalent in all cases. ${ }^{127}$ In this way, therefore, the RKC can be seen to have a substantial impact on EU customs regulations. In the aftermath of the 9/11 terrorist attacks, the United States was the first country to recognise terrorism as a threat to the security of the international trade supply chain. This encouraged the international trade community and customs administrations to develop the SAFE Framework as a global supply chain security initiative under the auspices of the WCO. This framework was unanimously adopted by the Directors General of Customs, representing the members of the WCO, in June 2005 and is one of the outcomes of the WCO's 'soft approach'128 to agree on non-legally binding instruments. Here, the United States used its political (and economic) power to establish nonbinding agreements while bypassing the established forums for collective decision-making. ${ }^{129}$

The core element of the SAFE Framework is its introduction of the legal concept of the 'Authorised Economic Operator' (AEO) into WCO members' customs legislation. ${ }^{130}$ Under this concept, customs authorities carry out a detailed assessment of economic operators' reliability and can grant AEO status as a means of increasing security in international trade while also facilitating legitimate trade. The benefits available to AEO certificate holders in the form of simplified customs formalities and improved security facilitations are intended to enable customs controls to be carried out more precisely and thus more effectively.

In addition to its origins in the SAFE Framework, the AEO concept constitutes one of the elements of the TFA. With the AEO having been integrated into the multilateral trade rules of WTO law, an operational AEO programme is now mandatory for all WTO members. This is in recognition of what such a programme can contribute to trade facilitation. Hence, the concept, which was originally considered a soft-law instrument, has been transformed through the TFA into a hard-law instrument. Under Article 7 para. 7.1 TFA, each WTO member must provide an AEO with additional tradefacilitation measures related to import, export or transit

125. Lux, above n. 19 , at 24

126. Under Council Decision 2003/231, OJ 2003 L 86, at 7 of recital. Accession to the revised specific annexes, contained in Appendix III to the Protocol of Amendment, will be decided at a later stage. For the structure of the RKC, see S.S. Hossain, 'Revised Kyoto Convention: The Best Practice Guide for Customs', 3(11/12) Global Trade and Customs Journal 383, at $384 \mathrm{ff}$. (2008).

127. Ibid

128. Yamaoka, above n. 115, at 94

129. D. Holloway, $9 / 11$ and the War on Terror (2008), at 44-45

130. H.M. Wolffgang and J.M. Natzel, 'The Authorized Economic Operator in the European Union', 2(11/12) Global Trade and Customs Journal 377 , at 377 (2007). 
formalities and procedures. The criteria for qualifying as an AEO relate to compliance, or the risk of noncompliance, with requirements laid down in domestic laws, regulations or procedures (Art. 7 para. 7.2 TFA). Thus, the SAFE Framework, compiled and still existing as soft law under the auspices of the WCO, has made its way towards hard law under the WTO.

The EU implemented the WCO's AEO model in $2008^{131}$ and has continued to apply the AEO concept under the new UCC. In this way, it has complied with the now binding requirement to implement a fullyfledged AEO programme under the TFA. The AEO concept has been described as an important, if not the most important, development in modern European customs law. Even if adopted voluntarily, the AEO element of customs legislation is now one of the many provisions that has been adopted in order to comply with international obligations.

In addition to the HS and RKC, the WCO administers a wide range of other international agreements, while the Convention on Temporary Admission ('Istanbul Convention'), ${ }^{132}$ which is directly applicable and thus has been only partly transposed into EU customs legislation, ${ }^{133}$ was also established under the auspices of the WCO.

\subsection{Other International Sources}

Another international instrument of relevance to the EU Customs Union is the Customs Convention on the International Transport of Goods under Cover of TIR Carnets ('TIR Convention'), which is administered by the United Nations Economic Commission for Europe (UNECE). The EEC acceded to the TIR Convention in $1978,{ }^{134}$ and this Convention has also been deemed to be directly applicable. ${ }^{135}$ By contrast, the Agreement on the Importation of Educational, Scientific and Cultural Materials ('Florence Agreement') was arrived at under the umbrella of the United Nations Educational, Scientific and Cultural Organization (UNESCO). This Agreement was adopted by the EEC in $1979^{136}$ and has been incorporated into the latest version of the Regulation governing the EU's system of reliefs from customs duty. ${ }^{137}$

\section{Remaining Autonomy for EU Legislation Governing the Customs Union}

This contribution has shown the wide range of international agreements impacting on legislation governing the EU Customs Union. International law has left an extensive footprint on the Customs Union. This, combined with the EU's implementing of certain soft-law international instruments in the form of nonbinding standards, shows that the EU has followed a pattern of seeking to achieve high global standardisation of import and export rules in order to facilitate cross-border trade. As far as the international instruments leave gaps for national or supranational provisions, these gaps are filled in conformity with the laws adopted in order to comply with international obligations, standards and recommendations.

Once legal acts applying to the EU Customs Union have been drafted, it is essential to enforce them. The need to implement the framework of relevant international provisions, stemming mostly from the WTO and WCO, has resulted in a high degree of international harmonisation of EU legislation governing the Customs Union. Any remaining areas have to be filled by legislation adopted by the EU and its member states. Even though EU customs legislation includes increasing numbers of exhaustive rules ${ }^{138}$ and the UCC has left fewer and fewer gaps for national legislation in comparison to earlier regulations, customs legislation still comprises a mix of EU and national legislation. ${ }^{139}$ The areas not influenced by international standards comprise not only provisions governing infringements and sanctions but also appeal procedures, provisions on the occurrence of customs debts and provisions relating to the collecting of customs duties. On this basis, around $90 \%$ of customs legislation in the EU Customs Union is estimated to be determined by international law and instruments.

\section{Conclusion}

This contribution has shown how, at its fiftieth anniversary, the EU Customs Union has evolved under the strong influence of international law. Over the years, the provisions of various international instruments, primarily deriving from the WTO and WCO, have found their way - independent of their legal nature - into the fundamental customs-related principles of EU legislation. While, internally, the EU Customs Union is designed to abolish most trade-restricting measures between its constituent members in accordance with GATT 1994, externally it is guided by the target to harmonise all trade-related relationships with third countries, also under the scope of GATT 1994. And the essential 'single currency' of external trade provisions has not stopped at customs legislation as it also extends to wide areas of trade-related legislation.

\footnotetext{
131. Ibid., at 377

132. See Council Decision 329/93, OJ 1993 L 130/1.

133. Lux, above n. 19 , at 22

134. Council Regulation 2112/78, OJ 1978 No. L 252/1.

135. Case C-78/01, BGL v. Germany, [2003] ECR I-9543 at 43.

136. Council Decision 79/505, OJ 1979 L134/13.

137. Council Regulation 1186/2009, OJ 2009 L 324/23.
}

138. On the right to representation before the customs authorities, see Case C-153/10, Staatssecretaris van Financiën v. Sony Supply Chain Solutions (Europe) BV, [2011] ECR I-02775, at 30; on the joint and several liability of several debtors for the same customs debt, see Case C-78/10, Berel and Others, [2011] ECR I-00717, at $41 \mathrm{ff}$.

139. Lyons, above n. 13, at 139. 
This process of evolution is set to continue, focusing on the concept of trade facilitation in order to make customs procedures more economically efficient. The concept of the AEO, introduced in the WCO's SAFE Framework and the WTO's TFA, must surely constitute a first important step in this process. However, while the EU may seem to represent a modern-day example of a customs union, addressing and incorporating into its legislation all the relevant provisions in international law, its promoting of further international harmonisation will result in its losing autonomy. 